\title{
|فنتاحية المدد
}

بسم الله الرحمن الرحيم وعلى بركة الله تبدأ مجلة جديدة في مجال المكتبات

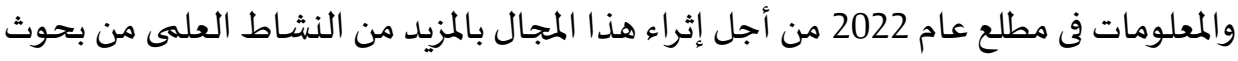

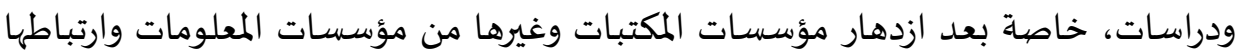

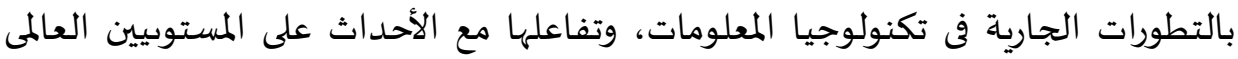

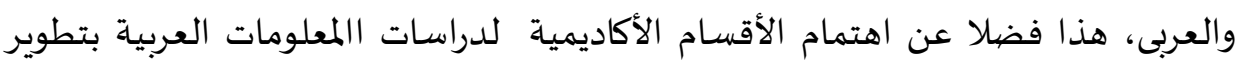

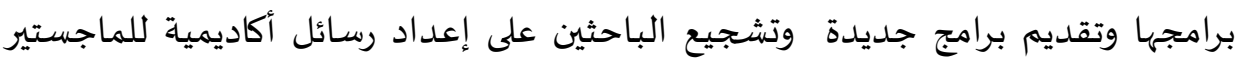

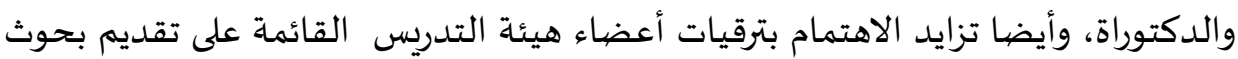
علمية مبتكرة .

وقد أدى ذلك إلى تقديم هذه المجلة كمنبر علمى عربى جديد للباحثين والدارسين

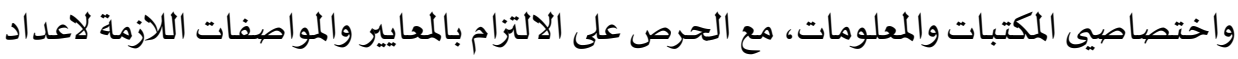

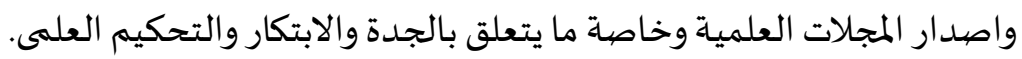
وتود أسرة هيئة التحرير للمجلة أن تشكر وتقدر المؤسسـة العربية لادارة المعرفة،

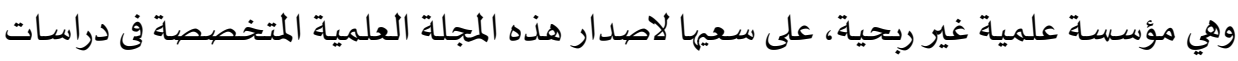
المكتبات والمعلومات.

إلى كل المهتمين والمنشغلين بالبحث العلمى فى مجال المكتبات والمعلومات فى سائر

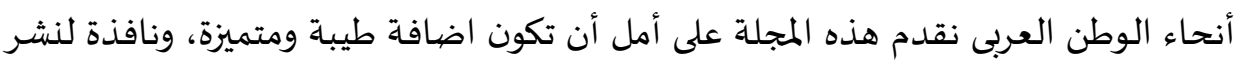

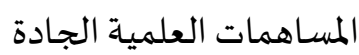

والله من وراء القصيد

\section{رئيس التحرير}

أ. د. محمد فتحى عبد الهادي 
أ.د. محممد فتحى عبد الهادي

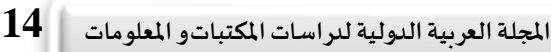
المجلد الأول - العدد الأول يناير 2022 